\title{
"There is competition": Facing the reality of field education in New Zealand
}

Kathryn Hay, Massey University, Palmerston North, New Zealand

\begin{abstract}
INTRODUCTION: Anecdotal evidence of increasing competition for field education placements has raised concerns about the availability of quality learning opportunities for students and so it was considered timely to examine stakeholder perspectives.

METHOD: In late 2014, 15 tertiary educators from 11 tertiary institutions and 31 social work students from three Aotearoa New Zealand tertiary institutions engaged with the researcher in individual or focus group interviews on aspects of quality field education.

FINDINGS: Overall, the tertiary educators revealed considerable pressure on them to secure quality student placements due to competition with other tertiary providers, limited placement opportunities in some locations, high workloads and inadequate funding. Students recognised these pressures but questioned whether the educators are adequately supported by the tertiary institution. Placement availability was also affected by organisations experiencing funding pressures, placement fatigue, limited space and physical resources, and high workloads.
\end{abstract}

CONCLUSIONS: These qualitative findings raise questions for all the key stakeholders in field education: tertiary institutions, educators, social service organisations, the professional associations, the regulatory body and students. The findings from this study signal the need for a comprehensive, sector-wide examination of the social work field education context in Aotearoa New Zealand.

KEYWORDS: field education; quality; New Zealand; placements; field educators; students; competition

AOTEAROA

NEW ZEALAND SOCIAL WORK 30(2), 16-27.

CORRESPONDENCE TO: Kathryn Hay

k.s.hay@massey.ac.nz

\section{Introduction}

The centrality of field education to the professional development of beginning social workers has been widely acknowledged (Kadushin, 1991; Parker, 2006). Often described as the most memorable aspect of student learning, and the cornerstone or signature pedagogy of social work education (Parker, 2006; Wayne, Bogo, \& Raskin, 2010), the benefits of field education across many disciplines are undisputed (Chilvers \&
Hay, 2011; Coll \& Zegwaard, 2011; Cooper, Orrell, \& Bowden, 2010). In Aotearoa New Zealand, students studying for social work qualifications that are recognised by the Social Workers Registration Board (SWRB) are required to undertake a minimum of 120 days of field education during the final two years of their programme (SWRB, 2017a). The SWRB further stipulates that students must have at least two placements. These placements must occur in two differently structured settings and fields of practice (SWRB, 2017a). 
In 2015, 3,885 students were enrolled in social work programmes across the 17 tertiary providers and 1,827 students had placements in both government and non-government settings (SWRB, 2016a). This appears to have been a peak in student numbers with enrolments declining to 3,337 in 2016 and further to 3,310 in 2017 (SWRB, 2016b, 2017b). Placement numbers have seen an equivalent decline with 1,660 placements required in 2016 and 1,272 in 2017. During this period, some schools of social work were engaged in a transition process of moving from a three- to four-year degree programme and therefore these enrolment patterns may, in part, be reflective of this process. Future enrolment numbers may therefore rise again with the embedding of the four-year programmes across the tertiary sector. Despite these institutional developments and the recent decline in student enrolments, anecdotal concerns continue regarding the availability of quality placements. The sustainability of current field education models thus needs urgent, but careful, consideration.

This article draws on findings from a study on quality field education that canvassed the perspectives of key stakeholders including agency managers, tertiary educators, students, the Aotearoa New Zealand Association of Social Workers (ANZASW), and the SWRB. The focus of this article is on factors that might affect the availability of quality student placements in Aotearoa New Zealand as discussed by 15 social work tertiary educators and 31 students.

\section{Literature review}

Recent research in field education from Australasia has tended to focus on the roles of key stakeholders including the tertiary educator or liaison, field educators and agency managers (Chilvers, 2018; Cleak \& Venville, 2018; Hanlen, 2013; Hay \& Brown, 2015; Hay, Dale, \& Yeung, 2016). The skills required for effective placement experiences have been examined (McCafferty, 2018) and there has been an increasing interest in international placement experiences (Hay et al., 2017; Zuchowski, Gopalkrishnan, King, $\&$ Francis, 2017). The negative effects of field education on students have been explored with the compulsory nature of placements being shown to be a burden, placing inordinate stress on students and potentially limiting optimal placement learning (Gair \& Baglow, 2018; Hemy, Boddy, Chee, \& Sauvage, 2016). Recommendations from Gair and Baglow's (2018) Australian study included increasing government financial support for tertiary students and greater flexibility in the social work curriculum, especially around field education. Elements of the practice environment such as assessment and supervision continue to receive attention (Cleak \& Venville, 2018; Hodgson \& Watts, 2016; Zuchowski, 2015). The consistent message throughout this literature, echoing earlier research (Kadushin, 1991; Maidment, 2003) is that placements remain the most powerful and memorable component of a student's learning during their qualifying programme. The variability of quality or effective learning opportunities and a persistent murmur about competition and availability of placements is however, evident and requires further attention.

\section{Competition for placements}

The levels of competition for placements and potential effects of these in Aotearoa New Zealand is difficult to measure.

Anecdotal reports of limited placements have existed for a long time (Tertiary Education

Commission, 2009) with claims such as:

Every school of social work has difficulty in placing students, either because of placement scarcity or insufficient opportunity for matching student characteristics with availability of places. (Hanlen, 2011, p. 229)

Hanlen's (2013) doctoral research examined the perspectives of non-government organisation managers on what influences them to accept students on placements. The findings from her study suggested that, 
from the perspectives of the managers, the extent of competition for placements was more significant than previous literature had indicated (Hay \& O'Donoghue, 2009). That said, no empirical research on the demand for social work placements had occurred in Aotearoa New Zealand until 2013.

Recognising the exponential growth of social work programmes in Aotearoa New Zealand since 2008 and the consequent increase in student enrolments, Hay, Ballantyne, and Brown (2014) endeavoured to map the demand for social work placements. Drawing on SWRB data acquired from social work programmes, they discovered that, in 2012, 1,374 placements were required across Aotearoa New Zealand (Hay et al., 2014). Their survey results signalled that a majority of tertiary education institutions (TEIs) anticipated increasing demand for placements in the following years. Their study also revealed inconsistencies in the quality and integrity of the SWRB data, which limited conclusions around the demand for placements (Hay et al., 2014). To date, no further published studies on the availability of, and competition for, social work placements in Aotearoa New Zealand have been located.

A recent study (Ayala et al., 2018) explored the perspectives of field education coordinators on the declared crisis in field education in Canada. They identified placement saturation as a critical issue and described this as "... the lack of sufficient numbers of practica to accommodate the increasing demand for placements from expanding social work education programmes" (p. 265). Their claims of significant shortages of placements has led to recommendations to considering alternative approaches to existing models of field education and enhancing collaboration between tertiary education programmes (Ayala et al., 2018).

\section{Role of the tertiary educator}

In Aotearoa New Zealand, the tertiary educators engaged in field education courses are employed as academic staff and are often referred to as placement or field education coordinators (ANZASW, 2016; SWRB, 2017a). They are responsible for understanding the field education context and building relationships with the complex network of people and organisations involved in placements (Jackson, 2018). Their role might include organising and allocating placements as well as teaching, monitoring and assessment. As Cleak and Venville (2018) describe, they may also mediate, problem-solve and act as gatekeepers. In their Australian study, these authors surveyed 53 students and 47 field educators on their levels of satisfaction with the tertiary educator (Cleak \& Venville, 2018). Their findings emphasised that students and field educators desired interactions with knowledgeable and experienced tertiary staff, preferably during face-to-face encounters. They recommended increasing resourcing levels and reducing workloads to strengthen the educational and liaison role of the tertiary educator (Cleak \& Venville, 2018).

Accessing sufficient placements that will enable student learning is a critical component of the tertiary educator role. In an environment of placement shortage, educators experience tension in the matching and allocation process as they seek "quality" experiences for their students (Gordon, McGeoch, \& Stewart, 2009). As Zuchowski's (2015) Australian research testified, tertiary educators must understand not only individual student needs, but also the regulatory and programme requirements and the organisational context to facilitate effective placements. The unfeasibly high workloads of tertiary educators have been identified as a critical element in the Canadian field education crisis (Ayala et al., 2018); however, there is a notable absence of published literature on the workloads of field education tertiary educators and how they manage the complexities of their role in Aotearoa New Zealand.

\section{Organisations and availability of placements}

The neoliberal policy environment in Aotearoa New Zealand requires social 
services to perform as outcome-focused businesses (O'Brien, 2016). These policies directly influence funding streams for social service organisations and the limited resources do not reflect the challenges or complexity of their activities (Ballantyne, Beddoe, Hay, Maidment, \& Walker, 2017; McCafferty, 2018). Financial constraints in social service organisations are a perennial issue frequently leading to high workloads, reduced staffing capacity and limited physical resources. The pressures arising from these constraints are longstanding (Beddoe \& Worrall, 1997; Maidment, 2003). They do, however, continue to affect the ability and willingness of organisations to take student placements (Hay \& Brown, 2015; McCafferty, 2018; Moorhouse, 2013). In an earlier publication, Maidment (2003) recognised the dependence of tertiary programmes on the social service sector to provide learning opportunities for students. The traditional model of field education whereby a student is placed in an organisation and generally receives support and supervision from one social worker or professional continues in Aotearoa New Zealand (Hanlen, 2013) despite occasional calls for consideration of alternative approaches (Maidment, 2003).

Hanlen (2013) thoroughly explored organisational pressures on non-government agency managers, identifying that a range of factors influence managers' decisions about accepting student placements. These factors include organisational pressures such as staffing capacity or restructuring, student characteristics, timing of the request, and macro influences including government provision of contracts. If accepted for a placement, students may be entering organisations that are pressured over time and resources and thus their learning may be jeopardised (Maidment, 2003; McCafferty, 2018). A framework of collective governance in field education whereby all key stakeholders have agency in the facilitation of the placement has been promoted by Australian researchers (Henderson \& Trede, 2017). They recommend the development of sustainable, reciprocal relationships although they recognise that organisations are likely to accrue less benefits than the student and the tertiary provider. While they emphasise that organisations need to support field educators through the provision of time, recognition and legitimation of their educative and supervisory role, they do not critique limiting factors such as funding and available physical resources (Henderson \& Trede, 2017).

McCafferty's (2018) findings from her Aotearoa New Zealand-based research with field educators echoed previous research (Hay \& Brown, 2015) that signalled some organisations are resistant to taking student placements because they receive no payment for this service. The stagnant resourcing of social work education which is funded at the social sciences rate is inadequate to cover the real costs of field education (Ballantyne et al., 2017; Chilvers, 2018) and the disparity with other professional disciplines such as nursing and teaching is undisputed. Surprisingly little has been written about the impact of the current funding levels in Aotearoa New Zealand and how this may influence organisations' willingness and ability to take student placements (Chilvers, 2018; Hay \& Brown, 2015).

\section{Method}

This study utilised a qualitative methodology and aimed to explore stakeholder perspectives on quality social work field education in Aotearoa New Zealand. The stakeholders included students, agency managers, tertiary educators, the ANZASW and the SWRB. Semi-structured interviews were conducted either individually or in focus groups, depending on preference and availability of participants. This article draws on tertiary educator and student views related to factors that may affect the availability of quality student placements in Aotearoa New Zealand.

The interview schedule was developed after familiarisation with the relevant literature 
including published material from previous stages of the study (Hay et al., 2014; Hay \& Brown, 2015). The interviews enabled the generation of data from the lived experiences and perspectives of two groups of people closely involved with field education (Ritchie, Lewis, McNaughton Nicholls, \& Ormston, 2014). Ethical approval from Massey University was sought and granted under the low-risk category. Confidentiality of the participants was given particular attention due to the limited number of educators and students engaged in social work field education in Aotearoa New Zealand. Consequently, the generated data and quotations are anonymised and any identifying information has been removed. Conflict of interest was avoided by ensuring that no educators or students from the researcher's institution were invited to participate in the research.

Programme heads of the 17 social work schools were emailed letters of invitation requesting that information sheets and interview schedules were forwarded to academic staff involved in field education courses and students who had completed at least one social work placement. Interested participants contacted the researcher directly to arrange either an individual interview or a focus group. As the student focus groups were held on the participating TEI's campus, the researcher liaised with relevant administration and academic staff to arrange a suitable location for the group interview.

Over the period June-December 2014, 15 tertiary educators from 11 TEIs participated in either individual interviews $(n=9)$ or focus groups $(n=2)$. These were conducted either by telephone or in person depending on convenience and the participants' preferences. The educators all taught in social work degree courses in either universities, polytechnics or wānanga ${ }^{1}$. They had all had recent, direct experience in field education activities including teaching, organising, monitoring, liaising and assessing placements. Students from three tertiary providers agreed to engage in focus groups on their campuses during November and December 2014. A total of 31 students participated in the focus groups. All of the students were enrolled in an undergraduate social work degree programme.

The interview data from the tertiary educators were analysed using qualitative analysis processes (Babbie, 2013) and, in particular, the Framework Approach (Ritchie et al., 2014). After the interviews were transcribed, the data were collated under the interview question headings. A thematic index was then developed for each question and charts that mapped the nature of the data and associations between themes were developed. The student focus group data were coded by the researcher using NVivo $11^{\mathrm{TM}}$. The generated node reports allowed the researcher to create thematic charts which allowed for further analysis of key themes relating to placement availability, the role of tertiary educators and organisational factors affecting availability of placements.

\section{Findings}

The tertiary educators and students voiced a range of opinions about the availability of social work placements and competition for quality placements. The pressure on tertiary educators engaged in field education was well-traversed with a continual refrain around limited funding and resourcing for this complex and time-intensive work, both for them and the field educators. Organisations that take student placements also face myriad pressures and the impact of this on placement availability and student learning was noted. These themes are further discussed below.

\section{Placement availability}

The pressure on finding suitable placements for students was discussed by all of the educators with the situation being described as a saturation crisis. They acknowledged the high number of social work programmes and consequent numbers of students seeking placement each year. They believed this 
had led to some organisations becoming more particular about the type of student they would accept, for example, someone without convictions or who had certain prior experiences. Further, there was a sense that organisations preferred to liaise with more established TEIs or those with whom they already held an existing relationship. This pressure to find placements may jeopardise student learning as some TEIs have to seek placements in new organisations or those seen to be less traditional:

The pressure for placements means that we know we are placing students in areas where they won't necessarily get a quality experience, what we would like them to have, because we have to push the boundary of what constitutes a placement ... that's always the dilemma. (Educator 6)

The consequences of this situation also seemed demoralising:

Just having a real shortage of placements, and then having to beg for placements, and putting pressure on staff in organisations where the timing's wrong, or they don't actually want a student but they take a student because the student has nowhere else to go. Or you shoulder tap your friends who are out in the community to take a student. (Educator 7)

The students held differing views as to whether they were competing against each other for placements and if this affected their agency preference. Tension was apparent in one focus group about the suitability of some of the placement agencies. Even after raising concerns with the tertiary educator they were dismayed that students the following year were still placed in the same organisation although they agreed this was due to the limited placements in that particular location:

I feel really sorry for those students, 'cos I don't think they're going to get very good learning. And I get that it's part of their availability of placements, all that, but it feels frustrating ... People that were at that placement were beside themselves, coming to class crying, and you know, that's not ok. And so and still in the year after, they sent people to that same place. (Student FG1)

The students suggested tertiary educators needed to undertake better planning of the placements including establishing that learning opportunities will exist for the students:

And speaking to those supervisors and finding out what the students could be working towards, who they would be shadowing, and just looking for those opportunities in order for us to achieve our goals. (Student FG2)

Similarly, the educators believed they needed to work more closely with field educators and their organisations to strengthen the links between industry and the tertiary sector. They suggested several ideas to assist this process including working alongside each other in the classroom, coconstructing case studies, having tertiary educators actively participating in agency work, and undertaking joint research. Inadequate levels of funding were cited as the primary limiting factor for the implementation of these ideas.

The students were emphatic about the need for more choices of placement. Two groups of students recognised the limited opportunities in the cities in which they lived, however, they questioned whether the tertiary educators had located all possible placement opportunities. One student seemed resigned to having to take whatever placement was available rather than one she was particularly interested in or thought would meet her learning needs:

So there's not really the opportunity to really have a proper fit for the student and the placement. You've just got 
to make it work. If you get in [to the placement] and then get in, great. You have to make it fit. (Student FG1)

The tertiary educators also discussed the matching and placement allocation process. There was a commitment from them to engage in matching individual students with specific placements and considering "the kind of supervisor you're putting them with, what kind of learning styles the student has ... what are some areas they might be challenged by..." (Educator 1). While this was noted as ideal, they acknowledged they often felt under pressure to confirm placements quickly especially due to competition with other TEIs:

There is competition. And that's why we have to work so hard on our relationships with our community ... because we want our local community, when they think about social work they think of [name of TEI] as being quality students, quality support and we want them to think that they have a close relationship with is, that they're engaged with us, so that there's trust there, so that they're more likely to say yes to us. (Educator 5)

Some students signalled a willingness to relocate for their placements if financial support was forthcoming from either the TEI or the placement organisation (Student FG1). The educators also supported this concept and agreed, "if we can't provide them a placement in the community area where they live, then we should be willing to put some money into that" (Educator 11). While this may not be suitable for all students depending on other responsibilities and commitments, this may take some pressure off some organisations and enable students to have excellent learning opportunities in other geographical locations.

\section{Pressure on tertiary educators}

The tertiary educators spoke passionately about the importance of field education in their social work programmes. They also explained at length many of the pressures associated with their role. They emphasised that all staff in the social work programmes needed to appreciate the value of field education and weave it into their teaching in the classroom so it is better integrated in the qualification. One tertiary educator explained:
So in my view, I think practicum sits at the heart of any social work degree but generally for some reason or another, it gets shunted off to the side as the poor cousin, or the big brother that's a bit naughty and we don't really know what to do with them. (Educator 1)

There was an awareness in all the student focus groups that the tertiary educators involved in the field education courses were under considerable pressure. One group of students suggested that the tertiary educator needed other colleagues to assist with the complex and time-constrained role. A different group discussed not wanting to "bother" the tertiary educator or ask too many questions due to their busy schedule. To enhance quality placements, the students encouraged TEIs to recognise the associated workload pressures:
Support the tutors so they have time to create a placement programme, e.g., the handbook, e.g., going out and finding the placements, so that they're paid to actually do the work, instead of ..., sometimes I think there's an attitude around social work where institutes view it as not so much a degree but it comes down the strata compared to things like business, stuff like that. But actually pay tutors to go out and find the placements give them time and it shouldn't be stuff that they have to do in their own time. (Student FG1)

The tertiary educators also described the complexity of their role and emphasised the importance of planning and giving consistent messages to students, field educators and organisational management. Several 
educators discussed limited administrative support or systems in their TEIs and that this placed a further burden on them. Time spent on administration impeded their direct work with students and agencies and also restricted time available for other tasks such as research. One educator described this tension:

They need to feel that time spent on supporting quality placements isn't time that's taken away from their research. It needs to be structured in a way that there's not that tension between "I must research" versus "I must provide everything that my student needs for placement" ... I don't think that that's always recognised within a university. (Educator 5)

The limited resources available to the tertiary educators was considered a key constraint. Additional funding for field education courses was repeatedly mentioned so that tertiary educators could then have more time to organise placements; visit the placements more frequently; develop new resources and innovations; support students who are required to travel and also offer a suite of training opportunities for field educators. Adequate funding would also signal the value of field education:

I'd really like placement papers to be funded realistically in accordance [with] the amount of work and the amount of hours that go into ensuring quality placements, ensuring that quality supervision is happening, to recognise the difficulties around finding quality placements. (Educator 5)

Payment of field educators and external supervisors was also highlighted as a gap in current resourcing and was deemed important to facilitate some reciprocity and recognise the critical role of these stakeholders. The lack of specific funding from the Tertiary Education Commission for social work programmes was seen as needing immediate attention. The educators believed this could significantly change the current pressured environment:

The university would not be so worried about money. It would only be concentrating on whether these students are fit for practice, whether there's jobs out there for them, and whether there's enough quality placements to ensure they get the learning they need within their training so that the numbers weren't based on "Hey, let's get as many as we can" but were based on how many quality placements we can know that we're going to get for those students. (Educator 6)

\section{Organisational factors}

Funding cuts or uncertainty of continuing contracts in social service organisations were acknowledged by the students as limiting factors on the availability of placements. They were aware that some agencies could not commit to taking a placement student due to their own staffing and service uncertainties. Also, the tertiary educators noted that they did not feel they could put too many expectations on organisations about taking placement students, especially if they were aware of organisational stressors. There was an associated sense of having to be grateful for a placement, even if the tertiary educator was aware of the funding and staffing pressures that were occurring and that these might negatively impact on the student's learning. In contrast, one tertiary educator indicated that organisational change can create learning opportunities for students, although they still needed to be well-supported:

...organisational change is actually part of social work. And so to try and protect your students from all of those variables that might interrupt their learning, actually that's a heap of learning ... [but] it might not be a pleasant experience. (Educator 6)

Funding pressures may also lead to redundancies, further limiting numbers of available staff. This, along with a lack of 
registered social workers in some agencies or geographical locations, can further affect placement availability and according to one educator, was a particular challenge in Māori organisations. The educators did not disagree with the SWRB regulations but instead emphasised the need to be creative, innovative and flexible in their placement planning.

The tertiary educators suggested that some organisations have placement fatigue due to an almost continual cycle of students, not always just from social work but also other disciplines. Some organisations also faced challenges housing students and providing them with resources such as a desk and chair, computer, telephone and a place to store their belongings. This was seen by both tertiary educators and students to be a basic expectation of the placement:

I think students can be really undermined if they don't have a space within the organisation ... it's ideal if they can have access to a computer that is their own and a phone so that they don't feel they're interrupting other workers. (Educator 5)

The students voiced frustration at not having their own physical space:

I found that hard at the placement I was just on, cause I didn't have anywhere to work and everyday it was a juggling match as to whose desk I could have, who wasn't going to be there and if there wasn't a desk then I had to sit at the round table in the manager's office and then if she had someone come in for a meeting I had to go and I'd just have to find somewhere to sit and I didn't have a desk. I found that really difficult. (Student FG1)

The tertiary educators recognised that field educators are generally balancing high workloads alongside their placement responsibilities and for this reason questioned whether it was fair to expect them to give up time to attend training or other professional development related to field education. Workload release time was recommended as a way "to recognise the work that it takes to have a student, or access to further education, professional development" (Educator 5) and again funding from TEIs for field educators was emphasised as necessary in order to support this approach and thereby promote excellence in field education.

\section{Discussion and conclusions}

Field education is central to the professional development of work-ready graduates (Smith, Ferns, \& Russell, 2016). With a reliance on several stakeholders for its success it is a complex endeavour that requires extensive time and resourcing to ensure its effectiveness.

The participants in this study confirmed the refrain of placement saturation and competition for placements that has been heard for many years in forums of tertiary educators and more recently between New Zealand government officials and sector representatives. However, there remains no empirical evidence that the students requiring placements on an annual basis are not being placed in suitable learning environments. The SWRB statistics instead indicate that students are being placed although whether all of these are in environments conducive to learning is unknown (SWRB, 2016a, 2016b, 2017b). There appears to be an urgent need to examine the claims of competition and limited availability of quality placements. Quality benchmarks can be determined through cross-sector consultation and the utilisation of existing tools such as the national Field Education Guidelines (ANZASW, 2016). Consideration of alternative models of field education, whilst maintaining a focus on the achievement of agreed learning outcomes and assessment, could facilitate new and exciting learning opportunities and reduce pressure on all stakeholders (Maidment, 2003). Interdisciplinary, research or project-focused 
work are examples of models that are, to some extent, now being offered as different learning opportunities to the traditional case-focused practicum (Maidment, 2003). Further cross-sector discussion on alternative models, including practical components such as the number of required days and frequency of supervision, are required to continue strengthening field education in Aotearoa New Zealand.

Echoing previous Aotearoa New Zealand research, the findings also highlight difficulty in securing appropriate placements in some geographical locations. The students in this study expressed an openness to undertake placements outside their geographical location if this guaranteed a quality learning experience. Financial support from TEIs could assist students with relocation if appropriate placements were available. Employers in organisations that might have difficulty recruiting social workers could also work alongside TEIs to identify appropriate students who could complete a placement with the intention of future employment. The introduction of organisational incentives such as subsidised rental accommodation, petrol vouchers or other financial assistance could further support this idea. Sustainable relationships and a shared focus on student learning between TEIs and organisations are foundational for the success or otherwise of such initiatives. As Chilvers' (2018) doctoral research highlighted, field educators do not always feel their work is sufficiently valued and increased resources and opportunities such as specific training in field education or time allocated to developing communities of practice might, at least in part, address this concern. Addressing the inadequate funding levels in social work education would greatly assist with such endeavours and, importantly, increase recognition of the field educators and organisations that support student learning.

In addition, organisations may hold preferences for students with specific attributes or from particular TEIs (Hay \& Brown, 2015). In recent years, national organisations including the Ministry for Children Oranga Tamariki and the Open Home Foundation have moved to regional administration of placements, effectively removing the ability for tertiary educators to directly liaise with local sites. This new development potentially alleviates some of the alleged favouritism of particular TEIs as all students are considered to be on an equal basis. Unfortunately, it also jeopardises the individual matching process between a student and a field educator as the latter are sidelined in the selection process and may not even have the opportunity to meet with a student or indicate their opinion as to their suitability prior to the commencement of the placement. This is concerning, as a transparent matching process and consideration of specific student attributes are elements that contribute to effective student placements (Hay et al., 2016). Individual, regional and national placement selection processes need to be comparatively evaluated so as to determine which method(s) are most efficacious, especially in ensuring optimal student learning and development.

In Aotearoa New Zealand, the neoliberal framework has significantly contributed to the shaping of social work education and social work practice contexts (O'Brien, 2016). The effects of contracting for services are evident in the comments from educators who directly associated funding uncertainty with a hesitation from organisations to take students on placement. Managers generally wish to offer students learning opportunities that enhance their personal and professional development (Hanlen, 2013; Hay \& Brown, 2015) and might be wary of accepting students into an environment that is being restructured or has limited staffing capacity. Similarly, insufficient physical resources might inhibit the offering of placements. Overall, the findings associated with the effect of the organisational context on placement availability and suitability align with the Canadian research on field education:

The context of the workplace is often characterised by a lack of resources, 
organisational restructuring, employee lay-offs, and productivity requirements that result in reduced capacities to accommodate social work students for practicum placements. (Ayala et al., 2018, p. 285)

There are limitations in this study including that the focus of the wider research was exploring aspects of quality field education. Therefore, some tertiary educators and students might not have felt it important to discuss their opinions on factors affecting the availability of placements. It is accepted that it cannot be argued that all educators and students would agree with the findings presented here.

Despite these caveats, it seems clear that the findings from this study signal the need for a comprehensive examination of the social work field education context in Aotearoa New Zealand. While not declared a crisis, at this point, the similarity of issues across the Canadian and New Zealand contexts is sobering (Ayala et al., 2018). Previous Aotearoa New Zealand research called for a "sector wide workforce strategy that endorses the importance of students for development of the profession and recruitment" (Hay et al., 2016, p. 52) and the findings presented here would validate such a process. A strategy that emphasises the learning culture of field education could also provide advantage for tertiary educators and field educators to negotiate workloads, physical resources and flexibility in the current field education model. Collaborative and transformational leadership in field education inclusive of key stakeholders could also be a significant and positive outcome (Chilvers, 2018). Most importantly, it would ensure field education remains the most memorable and important component of social work qualifying programmes rather than a burden on the next generation of social workers.

\footnotetext{
Note

${ }^{1}$ Tertiary institutions based on Māori philosophy.
}

\section{References}

Aotearoa New Zealand Association of Social Workers (ANZASW). (2016). Guidelines for field education. Retrieved from https://anzasw.nz/wp-content/uploads/ ANZASW-Social-Work-Field-Education-Guidelines.pdf

Ayala, J., Drolet, J., Fulton, A., Hewson, J., Letkemann, L., Baynton, M., ... Schweizer, E. (2018). Field education in crisis: Experiences of field education coordinators in Canada. Social Work Education, 37(3), 281-293.

Babbie, E. (2013). The practice of social research (13th ed.). Belmont, CA: Wadsworth: Cengage Learning.

Ballantyne, N., Beddoe, L., Hay, K., Maidment, J., \& Walker, S. (2017). Social work education, curriculum mapping and educational taxonomies. Ako Aotearoa. Wellington, NZ. Retrieved from https://akoaotearoa.ac.nz/sites/default/ files/ng/group-12305/Deliverable\%202.1\%20lit\%20 scan\%20FINAL\%207APR2017.pdf.

Beddoe, L., \& Worrall, J. (1997). The future of fieldwork in a market economy, Asia Pacific Journal of Social Work, $7(1), 19-32$.

Chilvers, D. (2018). Social work field educator practice: Expanding the vision (Unpublished Doctoral thesis). University of Canterbury, Christchurch, New Zealand.

Chilvers, D., \& Hay, K. (2011). Editorial. Aotearoa New Zealand Social Work, 23(4), 1-2.

Cleak, H., \& Venville, A. (2018). Testing satisfaction with a group-based social work field liaison model: A controlled mixed methods study. Australian Social Work, 71(1), 32-45.

Coll, R. K., \& Zegwaard, K. E. (2011). The integration of knowledge in cooperative education. In R. K. Coll \& K. E. Zegwaard (Eds.), International handbook for cooperative and work-integrated education: International perspectives of theory, research and practice (2nd ed., pp. 297-304). Lowell, MA: World Association for Cooperative Education.

Cooper, L., Orrell, J., \& Bowden, M. (2010). Work-integrated learning: A guide to effective practice. London, UK: Routledge.

Gair, S., \& Baglow, L. (2018). Australian social work students balancing study, work, and field practicum: Seeing it how it is. Australian Social Work, 71(1), 47-57.

Gordon, J., McGeoch, M., \& Stewart, A. (2009). Finding the way forward: Planning for practice learning in West of Scotland. Journal of Practice Teaching and Learning, 9(1), 46-63.

Hanlen, P. (2011). Social service managers and student information provision. Aotearoa New Zealand Social Work Review, 23(4), 65-75.

Hanlen, P. (2013). Fieldwork placement for social work students: What persuades managers to open the agency door? (Doctoral thesis). Curtin University, Perth, Australia.

Hay, K., Ballantyne, N., \& Brown, K. (2014). Hic sunt dracones: Here be dragons! Difficulties mapping the demand for social work practicums in New Zealand. Journal of Practice Teaching and Learning, 13(1), 24-43.

Hay, K., \& Brown, K. (2015). Social work practice practicums in Aotearoa New Zealand: Agency managers' perspectives. Social Work Education, 34(6), 700-715. 
Hay, K., Dale, M., \& Yeung, P. (2016). Influencing the future generation of social workers: Field educator perspectives on social work field education. Advances in Social Work and Welfare Education, 18(1), 39-54.

Hay, K., Lowe, S., Barnes, G., Dentener, A., Doyle, R., Hinii, G., \& Morris, H. (2017). "Times that by 100": Student learning from international practicum. International Social Work, Online 4 June, 2018. doi:10.1177/0020872817702707

Hay, K., \& O'Donoghue, K. (2009). Assessing social work field education: Towards standardising fieldwork assessment in New Zealand. Social Work Education, 28(1), 42-53. doi:10.1080/02615470802020881

Hemy, M., Boddy, J., Chee, P., \& Sauvage, D. (2016). Social work students "juggling" field practicum. Social Work Education, 35(2), 215-228. doi:10.1080/02615479.201 5.1125878 .

Henderson, A., \& Trede, F. (2017). Strengthening attainment of student learning outcomes during work-integrated learning: A collaborative governance framework across academia, industry and students. Asia-Pacific Journal of Cooperative Education, 18(1), 73-80.

Hodgson, D., \& Watts, L. (2016). Four principles of good assessment practice: A teaching and learning approach to designing and assessing student work. Advances in Social Work and Welfare Education, 18(1), 8-22.

Jackson, D. (2018). Developing graduate career readiness in Australia: Shifting from extra-curricular internships to work-integrated learning. International Journal of WorkIntegrated Learning, 19(1), 23-35.

Kadushin, A. (1991). Introduction. In D. Schneck, B. Grossman, \& U. Glassman (Eds.), Field education in social work: Contemporary issue and trends (pp. 11-12), Dubuque, IA: Kendall/Hunt.

Maidment, J. (2003). Developing trends in social work field education. Women in Welfare Education, 6, 1-12.

McCafferty, L. (2018). Social work skills for students prior to fieldwork practicum (Unpublished master's thesis). University of Otago, Dunedin, New Zealand.

Moorhouse, L. (2013). How do social work students perceive their fieldwork supervision experiences? (Unpublished master's thesis). Massey University, Palmerston North, New Zealand.

O'Brien, M. (2016). The triplets: Investment in outcomes for the vulnerable: Reshaping social services for (some) New Zealand children. Aotearoa New Zealand Social Work, 28(2), 9-21.

Parker, J. (2006). Developing perceptions of competence during practice learning. British Journal of Social Work, 36, 1017-1036.

Ritchie, J., Lewis, J., McNaughton Nicholls, C., \& Ormston, R. (2014). Qualitative research practice: A guide for social science students and researchers (2nd ed.). Los Angeles, CA: Sage.

Smith, C., Ferns, S., \& Russell, L. (2016). Designing workintegrated learning placements that improve student employability: Six facets of the curriculum that matter. Asia Pacific Journal of Cooperative Education, 17(2), 197-211.

Social Workers Registration Board (SWRB). (2016a). Social work recognised programmes annual report 2015. Unpublished report.
Social Workers Registration Board (SWRB). (2016b). Social work recognised programmes annual report 2016. Unpublished report.

Social Workers Registration Board (SWRB). (2017a). Programme recognition standards. Retrieved from http:// swrb.govt.nz/about-us/policies/.

Social Workers Registration Board (SWRB). (2017b). Social work recognised programmes annual report 2017. Unpublished report.

Tertiary Education Commission. (2009). Social work education in New Zealand. Unpublished report.

Wayne, J., Bogo, M., \& Raskin, M. (2010). Field education as the signature pedagogy of social work education. Journal of Social Work Education, 46(3), 327-339.

Zuchowski, I. (2015). Field education with external supervision: Supporting student learning. Field Educator, 5(2), 1-17.

Zuchowski, I. S., Gopalkrishnan, N., King, J., \& Francis, A. (2017). Reciprocity in international student exchange: Challenges posed by neo-colonialism and the dominance of the western voice. Aotearoa New Zealand Social Work, 29(1), 77-87. doi:10.11157/anzswjvol29iss1id235 